\title{
Valor Nutritivo da Silagem de Milho sob o Efeito da Inoculação de Bactérias Ácido- Láticas ${ }^{1}$
}

\author{
Paulo Henrique Mazza Rodrigues ${ }^{2}$, Stefano Juliano Tavares de Andrade ${ }^{2}$, Juliana Martins \\ Ruzante ${ }^{3}$, Felix Ribeiro de Lima ${ }^{2}$, Laércio Melotti ${ }^{2}$
}

\begin{abstract}
RESUMO - Os resultados obtidos com a inoculação microbiana de diferentes plantas forrageiras, para a produção de silagens, têm apresentado resultados conflitantes. Objetivou-se, com o presente estudo, avaliar os efeitos da inoculação microbiana da planta de milho, para a produção de silagem, sobre a digestibilidade total em carneiros. Oito carneiros machos e castrados foram distribuídos em um delineamento em cross-over, com dois períodos sucessivos ( 8 animais/tratamento), e os tratamentos corresponderam à silagem de milho controle (média de $28,6 \%$ de MS e 9,6\% de PB) ou sob efeito da inoculação com o produto Pioneer 1174 (Streptococcus faecium e Lactobacillus plantarum). Cada período experimental teve duração total de 21 dias, sendo os cinco últimos destinados à coleta de fezes e urina. A inoculação não alterou a digestibilidade total da MS (inoculada $=64,5 \%$ vs. controle $=64,6 \%), \mathrm{PB}(56,0 \%$ vs. $54,4 \%)$, ENN $(69,2 \%$ vs. $70,2 \%), \mathrm{FB}(56,3 \%$ vs. $54,6 \%)$, FDN (49,0\% vs. $52,2 \%)$, FDA (48,2\% vs. $48,6 \%)$, amido $(98,8 \%$ vs. $98,7 \%)$, NDT $(65,1 \%$ vs. $65,1 \%)$, retenção nitrogenada ( 0,59 vs. $0,65 \mathrm{~g}$ de N/animal/dia) ou consumo de MS (2,13 vs. $2,28 \%$ do PV), mas tendeu (P=0,0878) em aumentar a digestibilidade do EE (86,7\% vs. $85,0 \%)$. Os dados presentes não permitem recomendar a inoculação da planta do milho com bactérias ácido-láticas para produção de silagens.
\end{abstract}

Palavras-chave: digestão, ovinos, Zea mays

\section{Nutritive Value of Corn Silage under Effect of Inoculation with Lactic Acid Bacteria}

\begin{abstract}
The results of using lactic acid bacteria in ensiling has been conflicting. This study was conducted to evaluate the effects of microbially inoculated corn plant for silage production on total digestibility in wethers. Eight wethers were assigned to a crossover design, with two periods ( 8 animals/treatment) and treatments were: control corn silage (28.6\% DM and 9.6\% CP, on average) or under inoculation with Pioneer 1174 product (Streptococcus faecium and Lactobacillus plantarum). Each period extended for twentyone days, the last five used for feces and urine collection. The inoculation did not influence total digestibility of DM (inoculated $=64.5 \%$ vs. control $=64.6 \%), \mathrm{CP}(56.0 \%$ vs. $54.4 \%)$, FNE $(69.2 \%$ vs. $70.2 \%), \mathrm{CF}(56.3 \%$ vs. $54.6 \%)$, NDF $(49.0 \%$ vs. $52.2 \%), \mathrm{ADF}(48.2 \%$ vs. $48.6 \%)$, starch $(98.8 \%$ vs. $98.7 \%)$, TDN (65.1\% vs. $65.1 \%)$, N retention ( 0.59 vs. 0.65 g of N/animal/day) or DM intake (2.13 vs. $2.28 \%$ of $\mathrm{BW})$, but there was a tendency $(\mathrm{P}=0.0878)$ of increasing digestibility of $\mathrm{EE}(86.7 \%$ vs. $85.0 \%)$. Present data does not support to recomend lactic acid bacteria for inoculation of corn crop for silage production.
\end{abstract}

Key Words: digestion, sheep, Zea mays

\section{Introdução}

A qualidade da silagem de milho varia em função de fatores extrínsicos, como o manejo de confecção do silo, condições climáticas e microbiota epifítica, e intrínsicos, como o teor de matéria seca, carboidratos solúveis, poder tampão, nitratos e outras substâncias nitrogenadas da planta (Morais, 1995). Com o objetivo de minimizar as perdas decorrentes da ensilagem, otimizar o processo fermentativo, reduzir a deterioração aeróbia e aumentar o valor nutritivo, tem sido pesquisado o uso de inoculantes biológicos na ensilagem (Harrison \& Blauwiekel, 1994).
Aumento da produção de lactato durante o início da fermentação (Kung Jr. et al., 1993), melhora da recuperação da matéria seca após a fermentação (Cleale et al., 1990; Ely et al., 1982; Soderlund et al., 1986) e aumento dodesempenho animal (Meeske \& Basson, 1998; Cleale et al., 1990) têm sido relatados por alguns pesquisadores com a inoculação, entretanto, nem sempre a resposta é consistente ou os resultados significativos (Eichelberger et al., 1997; Chen et al., 1994; Bolsen et al., 1992; Luther, 1986; Shockey et al., 1985).

Objetivou-se,comopresenteestudo, avaliarainfluência dainoculaçãomicrobiana sobre adigestibilidade aparente in vivo e consumo voluntário da silagem da planta do milho.

\footnotetext{
${ }^{1}$ Projeto financiado pela Fundação de Amparo à Pesquisa do Estado de São Paulo (FAPESP).

2 Professor do Departamento de Nutrição e Produção Animal - FMVZ/USP, Av. Duque de Caxias Norte, 225 - CEP. 13630-000, Pirassununga-SP. E-mail: pmazza@usp.br

${ }^{3}$ Bolsista de Iniciação Científica (FAPESP).
} 


\section{Material e Métodos}

O trabalho foi conduzido nas dependências do Departamento de Nutrição e Produção Animal da Faculdade de Medicina Veterinária e Zootecnia da Universidade de São Paulo (Campus de Pirassununga).

A cultura de milho (Agroceres 5011) foi semeada no dia 21/01/98 e cortada com 106 dias de crescimento, em estádio de $50 \%$ da linha do leite. Após colhido e picado em fragmentos de tamanho teórico médio de partícula de $1,4 \mathrm{~cm}$, segundo metodologia proposta por Heinrichs (1996), o material original foi pesado e acondicionado em 16 silos piloto, confeccionados a partir de bombonas plásticas, com aproximadamente $90 \mathrm{~cm}$ de altura e $53 \mathrm{~cm}$ de diâmetro (capacidade de 200 litros), revestidas internamente com sacos plásticos transparentes. Os silos foram divididos em dois tratamentos, um controle e outro com adição do inoculante comercial Pioneer 1174 (Pioneer Sementes Ltda.), segundo as recomendações do fabricante: $50 \mathrm{~g}$ do produto para 90 litros de água e 2 litros da solução para cada tonelada de cultura. Segundo essas recomendações, o produto fornece $9,9.10^{7}$ unidades formadoras de colônia (Streptococcus faecium e Lactobacillus plantarum) por grama de forragem. Utilizou-se água destilada à temperatura ambiente para a diluição do inóculo. O inoculante comercial Pioneer 1174 foi escolhido em função de melhores resultados obtidos ao avaliar os inoculantes Sil-All (Alltech do Brasil Agroindustrial Ltda.), Silobac (Biotecnal) e Pioneer 1174, em ensaios fermentativos com cultura de milho ensilada em silos experimentais (resultados não apresentados).

Aproximadamente $100 \mathrm{~kg}$ de massa úmida foram colocados em cada silo, correspondendo a uma compactação de aproximadamente $500 \mathrm{~kg}$ de silagem $/ \mathrm{m}^{3}$. Os silos foram mantidos fechados por 311 dias em local abrigado.

Para avaliação da digestibilidade aparente, foram utilizados oito carneiros deslanados jovens, machos castrados, da raça Santa Inês, com peso vivo médio de 34,46 quilos (desvio-padrão de $\pm 1,69$ ), ao início do experimento. Os animais foram mantidos em gaiolas metabólicas, providas de cocho e bebedouro individuais, sendo os mesmos arreados com bolsas coletoras. Foi utilizado o delineamento em reversão simples, com sequência balanceada (cross-over), com dois períodos de coletas, perfazendo oito repetições por tratamento.

As dietas foram compostas das silagens (Tabela 1), adicionadas de $5 \mathrm{~g}$ de sal branco $(\mathrm{NaCl})$ e $5 \mathrm{~g}$ de suplemento mineral/animal/dia, fornecidas em duas refeições, às 8 e $16 \mathrm{~h}$. O consumo durante o período de coleta de fezes foi restrito a $80 \%$ do ad libitum, durante o período de adaptação. O suplemento mineral apresentava a seguinte composição por $\mathrm{kg}$ de produto: $146 \mathrm{~g}$ de $\mathrm{Ca}, 90 \mathrm{~g}$ de $\mathrm{P}, 14 \mathrm{~g}$ de $\mathrm{Mg}, 15 \mathrm{~g}$ de $\mathrm{S}, 105 \mathrm{~g}$ de Na, $4.800 \mathrm{mg}$ de $\mathrm{Zn}, 1.500 \mathrm{mg} \mathrm{de} \mathrm{Cu}, 1.200$ mg de Mn, $2.300 \mathrm{mg}$ de Fe, $150 \mathrm{mg}$ de Co, $180 \mathrm{mg} \mathrm{de}$ I, $18 \mathrm{mg}$ de Se, $900 \mathrm{mg}$ de $\mathrm{F}$ (máximo).

Cada período experimental teve duração total de 21 dias, dos quais os primeiros 13 dias foram destinados à adaptação dos animais às dietas. Entre o $9^{\circ} \mathrm{e}$ $13^{\circ}$ dia, foi feita a mensuração do consumo; entre o $14^{\circ}$ e $21^{\circ}$ dia, a restrição do consumo; e entre o $17^{\circ}$ e $21^{\circ}$ dia, a coleta de fezes, urina e ingredientes da dieta para avaliação da digestibilidade in vivo e retenção nitrogenada.

As coletas de fezes, obtidas das bolsas coletoras, foram realizadas uma vez ao dia e reunidas para formar uma amostra composta. Após serem pesadas, uma amostra de $10 \%$ foi armazenada a $-15^{\circ} \mathrm{C}$. A urina foi coletada diariamente em baldes plásticos contendo $50 \mathrm{~mL}$ de ácido clorídrico concentrado 1:1. Uma amostra composta, referente a $5 \%$ do total produzido, foi armazenada a $5^{\circ} \mathrm{C}$ até o momento de realização das análises. As análises bromatológicas de MS, PB, EE, FB e MM foram realizadas segundo AOAC (1980) e de FDN e FDA segundo Goering \& Van Soest (1970). Para a análise de FDN foi omitido o sulfito de sódio, mas adicionada a $\alpha$-amilase. A

Tabela 1 - Composição bromatológica da silagem de milho controle e inoculada (porcentagem com base na MS) Table 1 - Chemical composition of control and inoculated corn silage (percentage as DM basis)

\begin{tabular}{|c|c|c|c|c|c|c|c|c|c|c|}
\hline Silagem & MS & PB & $\mathrm{EE}$ & MM & FB & FDN & FDA & Amido & $\mathrm{Ca}$ & $\mathrm{P}$ \\
\hline Silage & $D M$ & $C P$ & $E E$ & Ash & $C F$ & $N D F$ & $A D F$ & Starch & & \\
\hline $\begin{array}{l}\text { Controle } \\
\text { Control }\end{array}$ & 29,03 & 9,43 & 2,91 & 3,71 & 22,12 & 53,26 & 30,31 & 24,95 & 0,32 & 0,15 \\
\hline $\begin{array}{l}\text { Inoculada } \\
\text { Inoculated }\end{array}$ & 28,21 & 9,85 & 3,01 & 3,78 & 21,87 & 49,63 & 29,96 & 26,86 & 0,36 & 0,16 \\
\hline
\end{tabular}

R. Bras. Zootec., v.31, n.6, p.2380-2385, 2002 
concentração de amido foi avaliada segundo Pereira \& Rossi (1995), modificando esta metodologia para a prévia extração dos carboidratos solúveis, segundo metodologia proposta por Hendrix (1993).

Os resultados foram submetidos à análise de variância (SAS, 1985), que separou, como causas de variação, efeito de inoculante e efeito de período amostral. Adotou-se o nível de significância de 5\%, exceto quando especificado.

\section{Resultados e Discussão}

A digestibilidade dos nutrientes da silagem de milho, bem como os teores de nutrientes digestíveis totais (Tabela 2), apresentaram valores compatíveis aos encontrados na literatura (NRC, 1989), com composição bromatológica também próxima ao esperado (Tabela 1).

A adição de inoculantes à planta de milho para a produção de silagens não alterou a digestibilidade aparente da matéria seca, proteína bruta, extrativos não nitrogenados, fibra bruta, fibra em detergente neutro, fibra em detergente ácido e amido, bem como os nutrientes digestíveis totais (Tabela 2). A retenção nitrogenada também não foi alterada, fossem os dados expressos em gramas de N/dia ou em porcentagem do $\mathrm{N}$ absorvido. Observou-se apenas uma tendência $(\mathrm{P}=0,0878)$ da silagem submetida à inoculação apresentar maior digestibilidade do extrato etéreo, em relação à silagem controle. $\mathrm{O}$ aumento da digestibilidade do extrato etéreo, da ordem de $2,1 \%$ ( 1,8 unidades percentuais), apresentada pela

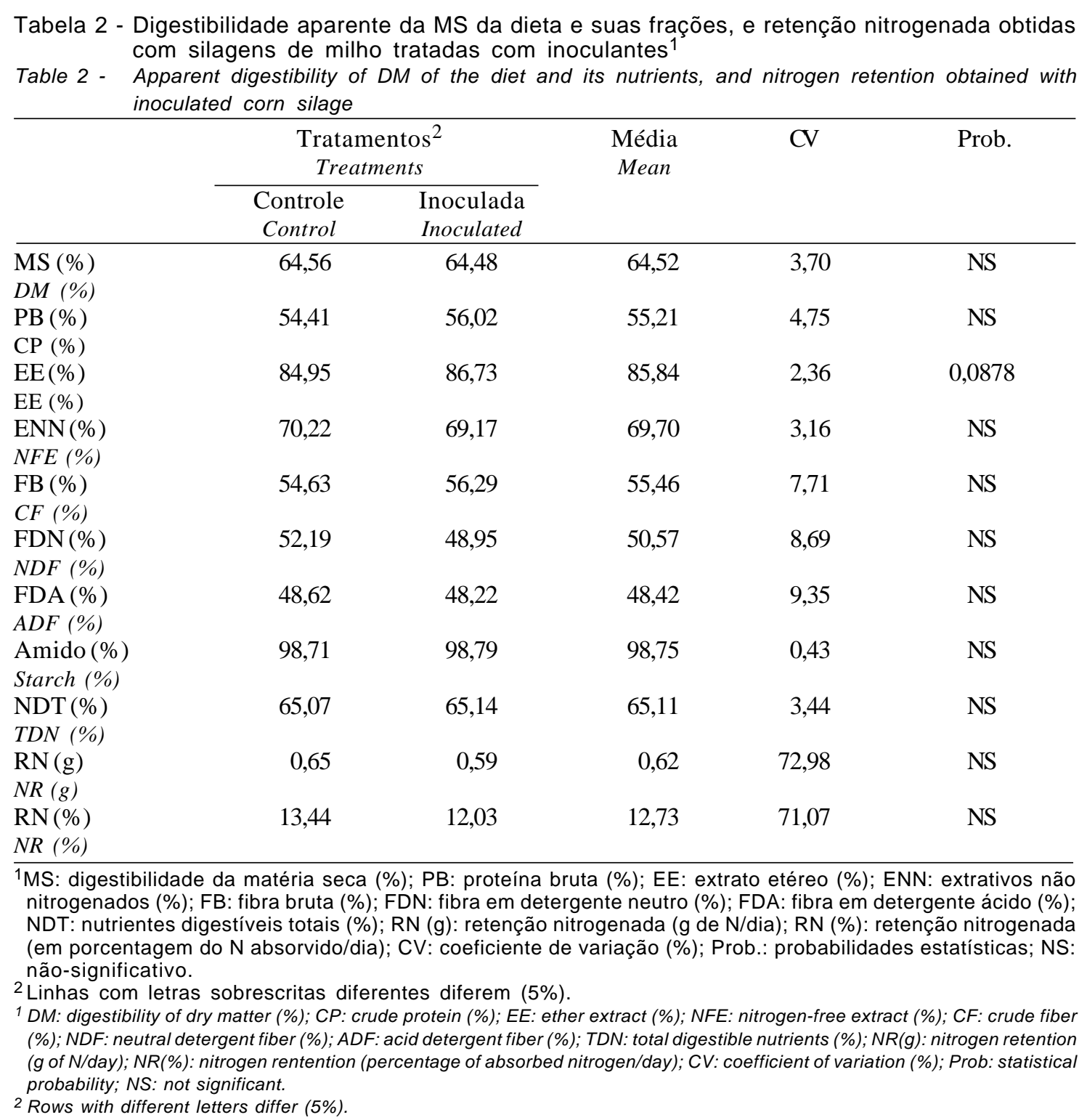

R. Bras. Zootec., v.31, n.6, p.2380-2385, 2002 
silagem sob inoculação, não foi capaz de causar reflexos sobre os valores de NDT.

Mesmo com a ausência de suplementação energética e protéica, observou-se que os animais apresentaram balanço nitrogenado ligeiramente positivo, com ganho de aproximadamente 0,62 gramas de nitrogênio/animal/dia, independentemente do tipo de silagem testada (Tabela 2). A ausência de suplementação energética e protéica, adotada no presente experimento, teve como objetivo evitar a diluição das possíveis respostas obtidas com o processo de inoculação microbiana.

Alguns estudos têm demonstrado efeitos benéficos do uso de inoculantes microbianos sobre a digestibilidade da FDN (Schaefer et al., 1989) e da digestibilidade da matéria seca e matéria orgânica (Luther, 1986) da silagem da planta do milho. Entretanto, concordando com os resultados aqui encontrados, Sanderson (1993) não observou efeitos da inoculação microbiana (Lactobacillus plantarum e Streptococus faecium) sobre a digestibilidade in vitro da FDN e FDA da silagem de milho, ensilada por 30 ou 160 dias de duração, embora a inoculação tivesse diminuído o $\mathrm{pH}$ da silagem. Da mesma forma, Daenicke et al. (1999) também não observaram efeitos da inoculação microbiana (Lactobacillus plantarum) da planta de milho, para produção de silagem, sobre a digestibilidade aparente da matéria seca e demais nutrientes, em ensaios conduzidos com carneiros.

Hunt et al. (1993) observaram, ainda, diminuição da digestibilidade in vitro da matéria seca, ao utilizar o mesmo inoculante microbiano aqui testado (S. faecium e L. plantarum), para inocular dois diferentes híbridos de milho para a produção de silagens, embora o desaparecimento in situ da matéria seca e a digestibilidade in vitro da FDN não tivessem sido alterados. Os autores explicaram os resultados em virtude de uma hidrólise parcial da hemicelulose, desencadeada com o processo de inoculação microbiana. Phillip \& Fellner (1992) também demonstraram tendência de diminuição da digestibilidade aparente da matéria orgânica e diminuição significativa da digestibilidade da FDA, ao inocular (Lactobacillus plantarum) grãos de milho de alta umidade para produção de silagem. Esses autores não foram capazes de explicar tal achado.

A adição de inoculantes à planta de milho não alterou o consumo de matéria seca, matéria seca digestível ou de nutrientes digestíveis totais, seja expresso em gramas ou em porcentagem do peso vivo (Tabela 3 ). De forma geral, o consumo de matéria seca, que em média foi de 2,2\% do peso vivo,

Tabela 3 - Consumo de matéria seca, de matéria seca digestível e de nutrientes digestíveis totais obtidos com silagens de milho tratadas com inoculantes ${ }^{1}$

Table 3 - Intake of dry matter, digestible dry matter and total digestible nutrients obtained with inoculated corn silage

\begin{tabular}{|c|c|c|c|c|c|}
\hline & \multicolumn{2}{|c|}{$\begin{array}{c}\text { Tratamentos }^{2} \\
\text { Treatments }\end{array}$} & \multirow[t]{2}{*}{$\begin{array}{l}\text { Média } \\
\text { Mean }\end{array}$} & \multirow[t]{2}{*}{$\mathrm{CV}$} & \multirow[t]{2}{*}{ Prob. } \\
\hline & $\begin{array}{c}\text { Controle } \\
\text { Control }\end{array}$ & $\begin{array}{l}\text { Inoculada } \\
\text { Inoculated }\end{array}$ & & & \\
\hline $\begin{array}{l}\text { CMS }(\mathrm{g} / \mathrm{d}) \\
D M I(g / d)\end{array}$ & 726,14 & 700,74 & 713,44 & 10,68 & NS \\
\hline $\begin{array}{l}\text { CMS (\%PV) } \\
D M I(\% B W)\end{array}$ & 2,28 & 2,13 & 2,20 & 10,95 & NS \\
\hline $\begin{array}{l}\operatorname{CMSD}(\mathrm{g} / \mathrm{d}) \\
D D M I(g / d)\end{array}$ & 467,65 & 451,33 & 459,49 & 9,61 & NS \\
\hline $\begin{array}{l}\text { CMSD }(\% \mathrm{PV}) \\
D D M I(\% B W)\end{array}$ & 1,46 & 1,37 & 1,42 & 9,87 & NS \\
\hline $\begin{array}{l}\operatorname{CNDT}(\mathrm{g} / \mathrm{d}) \\
T D N I(g / d)\end{array}$ & 471,60 & 456,05 & 463,82 & 9,83 & NS \\
\hline $\begin{array}{l}\text { CNDT }(\% \mathrm{PV}) \\
T D N I(\% B W)\end{array}$ & 1,48 & 1,38 & 1,43 & 9,91 & NS \\
\hline
\end{tabular}

${ }^{1}$ CMS: consumo de matéria seca; CMSD: consumo de matéria seca digestível; CNDT: consumo de nutrientes digestíveis totais, expresso em $\mathrm{g} / \mathrm{animal} / \mathrm{dia}(\mathrm{g} / \mathrm{d})$ ou porcentagem do peso vido (\%PV); CV: coeficiente de variação (\%); Prob: probabilidades estatísticas; NS: não-significativo.

2 Linhas com letras sobrescritas diferentes diferem (5\%).

${ }^{1}$ DMI: dry matter intake; DDMI: digestible dry matter intake; TDNI: total digestible nutrients intake, expressed in g/animal/day

$(\mathrm{g} / \mathrm{d})$ or percentage of body weight (\%BW); CV: coefficient of variation (\%); Prob: statistical probability; NS: not significant.

2 Rows with different letters differ (5\%). 
apresentou-se dentro do esperado, uma vez que a fermentação de ambas as silagens apresentou-se sensorialmente normal, sem fermentações indesejáveis. Quaisquer das silagens testadas não apresentaram bolores, áreas apodrecidas ou odores indesejáveis.

À semelhança do observado nesta pesquisa, o consumo de matéria seca não foi alterado pela inoculação microbiana (Lactobacillus plantarum) da planta de milho, por vacas recebendo dieta mista com concentrados e produzindo ao redor de $27 \mathrm{~kg}$ de leite/animal/dia (Daenicke et al., 1999). Phillip \& Fellner (1992) também não demostraram efeitos da inoculação de grãos úmidos de milho para ensilagem sobre o consumo de matéria seca em novilhos.

Recentemente, Jochmann et al. (1998) revisaram a literatura a respeito dos efeitos da inoculação microbiana sobre o valor nutritivo da silagem de milho e da alfafa. Entretanto, esses autores não puderam tirar conclusões seguras a respeito da inoculação do milho, em virtude do reduzido número de estudos encontrados na literatura. A contagem de bactérias epifíticas encontrada na forrageira tem sido comumente utilizada para explicar a grande variedade de resultados obtidos com a inoculação microbiana (Sanderson, 1993). Embora não tivesse sido avaliada no presente estudo, aparentemente, a população de bactérias láticas na planta do milho estaria suficiente, uma vez que quantidades adicionais dessas bactérias não causaram resposta.

\section{Conclusões}

Com base nas condições do presente experimento, nãoé possível recomendar a utilização do inoculante Pioneer 1174 para inoculação da planta de milho, uma vez que silagens sob efeito da inoculação não proporcionaram maior disponibilidade de nutrientes ou maior consumo de matéria seca.

\section{Agradecimento}

À Fundação de Amparo à Pesquisa do Estado de São Paulo (FAPESP), pelo financiamento do projeto; aos funcionários Everson Lázaro e Gilmar Botteon, pelo cuidado com os animais; e aos técnicos Ari de Castro, Gilson de Godoy e Simi Robassini, pelas análises laboratoriais.

\section{Literatura Citada}

ASSOCIATION OF OFFICIAL ANALYTICAL CHEMISTS AOAC. Official methods of analysis. 10.ed. Washington, D.C.: 1980. 1015p.

BOLSEN, K.K.; LIN, C.; BRENT, B.E. et al. Effect of silage additives on the microbial succession and fermentation process of alfafa and corn silages. Journal of Dairy Science, v.75, n.11, p.3066-3083, 1992.

CHEN, J.; STOKES, M.R.; WALLACE, C.R. Effects of enzymeinoculant systems on preservation and nutritive value of haycrop and corn silage. Journal of Dairy Science, v.77, n.1, p.501-512, 1994.

CLEALE, R.M.; FIRKINS, J.L.; Van DE BEEK, F. et al. Effect of inoculation of whole plant corn forage with Pediococcus acidilactili and Lactobacillus xylosus on preservation of silage and heifer growth. Journal of Dairy Science, v.73, n.3, p.711-718, 1990.

DAENICKE, R.; JOCHMANN, K.; GADEKEN, D. et al. Influence of lactic acid bacteria as inoculant in corn silage on digestibility of crude nutrients and performance of dairy cows. Landbauforschung Volkenrode, p.49, n.1, p.64-69, 1999.

EICHELBERGER, L.; SIEWERDT, L.; JUNIOR, P.S. Efeitos da inclusão de níveis crescentes de forragem de soja e uso de inoculantes na qualidade da silagem de milho. Revista Brasileira de Zootecnia, v.26, n.5, p.867-874, 1997.

ELY,L.O.; SUDWEEKS, E.M.; MOON, N.J. Chemical evaluation of Lactobacillus addition to alfafa, corn, sorghum and wheat forrage at ensiling. Journal of Dairy Science, v.65, n.4, p.1041-1046, 1982.

GOERING, H.K.; Van SOEST, P.J. Forage fiber analysis: apparatus, reagents, procedures and some applications. 1.ed. Washington. D.C.: ARS-USDA, 1970. p.1.

HARRISON, J.H.; BLAUWIEKEL, R. Fermentation and utilization of grass silage. Journal of Dairy Science, v.77, n.10, p.3209-3235, 1994.

HEINRICHS, J. Evaluating particle size of forages and TMRs using the Penn State Paticle Size Separator. 1.ed. Philadelphia: The Pennsylvania State University, 1996. 15p.

HENDRIX, D.L. Rapid extraction and analysis of nonstructural carbohydrates in plant tissues. Crop Science, v.33, n.6, p.1306-1311, 1993.

HUNT, C.W.; KEZAR, W.; HINMAN, D.D. et al. Effects of hybrid and ensiling with and without a microbial inoculant on the nutritional characteristics of whole-plant corn. Journal of Animal Science, v.71, n.1, p.38-43, 1993.

JOCHMANN, K.; LEBZIEN, P.; FLACHOWSKY, G. Influence of lactic acid bacteria as inoculant on rumen fermentation, digestibility of silages as well as on performance of dairy cows. Ubersichten zur Tierernahrung, v.26, n.1, p.123-155, 1998.

KUNG Jr., L.; CHEN, J.H.; KRECK, E.M. et al. Effect of microbial inoculants on the nutritive value of corn silage for lactating dairy cows. Journal of Dairy Science, v.76, n.12, p.3763-3770, 1993.

LUTHER, R.M. Effect of microbial inoculation of whole plant corn silage on chemical characteristics, preservation and 
utilization by steers. Journal of Animal Science, v.63, n.5, p.1329-1336, 1986.

MEESKE, R.; BASSON, H.M. The effect of a lactic acid bacterial inoculant on maize silage. Animal Feed Science and Technology, v.70, n.3, p.239-247, 1998.

MORAIS, J.P.G. Avaliação do efeito de inoculantes bacterianos sobre a qualidade da silagem e desempenho animal. Piracicaba, SP: ESALQ, 1995. 77p. Dissertação (Mestrado em Ciência Animal e Pastagem) - Escola Superior de Agricultura "Luiz de Queiroz"/Universidade de São Paulo, 1995.

NATIONAL RESEARCH COUNCIL - NRC. Nutrient requirenents of dairy cattle. 6.ed. Washington, D.C.: National Academy of Science. 1989. 157p.

PEREIRA, J.R.A., ROSSI JR., P. Manual prático de avaliação nutricional de alimentos. Piracicaba: Fundação de Estudos Agrários "Luiz de Queiroz”, 1995. 25p.

PHILLIP, L.E.; FELLNER, V. Effects of bacterial inoculation of high-moisture ear corn on its aerobic stability, digestion, and utilization for growth by beef steers. Journal of Animal Science, v.70, n.10, p.3178-3187, 1992.

SANDERSON, M.A. Aerobic stability and in vitro digestibility of microbially inoculated corn and sorghum silages. Journal of Animal Science, v.71, n.2, p.505-514, 1993.
SAS INSTITUTE. SAS user's guide: statistics. 5.ed. Cary: 1985.

SCHAEFER, D.M.; BROTZ, P.G.; ARP, S.C. et al. Inoculation of corn silage and high-moisture corn with lactic acid bacteria and its effect on the subsequent fermentations and on feedlot performance of beef steers. Animal Feed Science and Technology, v.25, n.1, p.23-28, 1989.

SHOCKEY, W.L.; DEHORIRY, B.A.; CONRAD, H.R. Effects of microbial inoculant on fermentation of alfafa and corn. Journal of Dairy Science, v.68, n.11, p.3076-3080, 1985.

SODERLUND, S.D.; RICE, D.W.; HINDS, M.A. et al. Effects of Pioneer brand 1177 silage inoculant on nutrient preservation and feeding value of whole plant corn silage. Journal of Animal Science, v.63, p.289, 1986. (Suplemento)

Recebido em: 21/01/02

Aceito em: 12/08/02 